cial group-in this case, the profession of librarianship-to maintain itself in its existing form.

The seventh part, "The Adaptive Subsystem," consists of articles on the identification of research needs, new directions, roles, and technological applications.

This is an excellent selection of articles contained within a meaningful and coherent framework which reflects the full range and variety of library and information services. This volume is recommended for study by graduate students in library and information sciences and for practicing librarians interested in their continuing professional development and desiring a fresh new look and perspective for a field that too often exhibits characteristics hidebound by tradition.-Michael B. Binder, Head Librarian, Clinch Valley College of the University of Virginia, Wise.

Balnaves, John, and Biskup, Peter. Austra-

lian Libraries. $2 \mathrm{~d}$ ed. (Comparative $\mathrm{Li}-$

brary Studies) Hamden, Conn.: Linnet

Books and Clive Bingley, 1975. 191p. (LC 75-1258) (ISBN 0-208-01361-X)

From 1935 to 1965 Australian libraries expanded rapidly; the enormous growth after years of virtual stagnation was recorded in John Balnaves' Australian Libraries, published in 1966. Although the events of the past eight years are in no way comparable, they have been substantial enough to warrant a second edition, completely revised and rewritten by John Balnaves and Peter Biskup. Balnaves, formerly head of the Bibliographical Services Section of the National Library of Australia, is now principal lecturer in librarianship at the Canberra College of Advanced Education, where Biskup serves as senior lecturer in librarianship.

Even though the book, a historical and structural account of the growth of Australian libraries from colonial days to the present, is twice the length of the first edition, it is still concise, well organized, and very readable. The authors were careful to point out in the preface that the increase in length is not a sign of a "more detailed treatment," but an indication of the continuing growth of Australian libraries. Other factors contributing to this increase are the larger, more agreeable typeface, and the useful addition of "further reading" to each chapter. Three chapters have been added on school, archives and manuscripts, and state libraries.

Most expansion in recent years has been in the area of public and school library service, bringing the Australians closer to their goal of national coverage. Colleges of Advanced Education have emerged, while the creation of new universities has leveled off. The emphasis has shifted to consolidation and utilization of existing resources. This new era of stabilized growth has freed Australian librarians to exploit international data bases and to develop national ones. As in the old edition, the authors make comparisons with the library scene in Englishspeaking parts of the globe.

Careful attention has been paid to the reviews of the first edition, and their factual and editorial recommendations have been incorporated into the revised text. The map in the original edition, described by one reviewer as inadequate, has been omitted from the revised text, a serious oversight. Now the only map appears on the dust jacket, to which'readers do not always have access.

Throughout the second edition substantial use is made of acronyms that are not necessarily connected, when first used, with the full name, which can be frustrating. On page 37 the acronym "STISEC" appears referring to a committee, but nowhere on this page or on those preceding it is the committee's full name given; this shows up later. If, however, Australian Libraries is directed toward a national market, this presents no problem. Nor does the fact that the two internal territories of Australia, the Capital Territory and the Northern Territory, could be discussed more fully in the first chapter. The authors state in the preface that they do not intend to cover Papua and New Guinea, but give no indication that they will neglect the Northern Territory, which is only mentioned briefly in a couple of places. Those unfamiliar with Australia may not realize that this is an exceedingly isolated and underdeveloped area.

Any librarian planning to immigrate to Australia or to work there should read this book. The authors in their conclusion chide most Australian librarians for emphasizing "the inadequacies rather than the achievements of their library systems." This is a 
fault that they do not share, for a sense of pride in the accomplishments of the Australian library field is evident, more so perhaps than in the first edition.-Judith Cannan, Associate Librarian, Serials Department, Cornell University Libraries, Ithaca, New York.

\section{OTHER PUBLICATIONS OF INTEREST TO ACADEMIC LIBRARIANS}

AAAS Science Film Catalog. New York: Bowker, 1975. 398p. \$16.95. (LC 7511536) (ISBN 0-8352-0860-5)

American Library Philosophy; An Anthology. Selected by Barbara McCrimmon. Hamden, Conn.: Shoe String, 1975. 248p. $\$ 10.00$. (LC 75-9544) (ISBN 0-208-01503-5)

American Society for Information Science. Information Utilities. Proceedings of the 37th Annual Meeting. Ed. by Pranas Zunde. Washington, D.C.: American Society for Information Science, 1974. 278p. (LC 64-8303) (ISBN 0-87715411-2)

Andrews, Theodora. A Bibliography of the Socioeconomic Aspects of Medicine. Litleton, Colo.: Libraries Unlimited, 1975. 224p. $\$ 10.00$. (LC 74-34054) (ISBN 0-87287-104-5)

Automated Activities in Health Sciences Libraries. (Vol. 1, issue 1, Library Automation at the Mayo Clinic Library.) Tempe, Ariz.: LARC Association, 1975- . Quarterly. \$40.00, member; $\$ 50.00$, nonmember.

Axford, H. William, ed. Proceedings of the LARC Institute on Cooperative Library Automation, Held February 14-15, 1974, at the University of Wisconsin. Tempe, Ariz.: LARC Association, n.d. 81p. (ISBN 0-88257-106-0, pap.)

Biographical Dictionaries Master Index 1975-1976: A Guide to More Than 800,000 Listings in Over Fifty Current Who's Who and Other Works of Collective Biography. 1st ed. Detroit: Gale, 19753 v. $\$ 65.00$ set. (75-19059) (ISBN 08103-1077-5)

Canadian Essay and Literature Index 1973. Ed. by Andrew D. Armitage and Nancy Tudor. Buffalo, N.Y.: University of Toronto Pr., 1975. 445p. \$27.50. (LC 757703) (ISBN 0-8020-4518-9)
Cooper, David E. International Bibliography of Discographies: Classical Music and Jazz and Blues, 1962-1972; A Reference Book for Record Collectors, Dealers, and Libraries. Littleton, Colo.: Libraries Unlimited, 1975. 272p. $\$ 13.50$. (LC 75-4516) (ISBN 0-87287-108-8)

Europe's 5000 Largest Companies. New York: Bowker, 1975. 299p. $\$ 35.00$ (ISBN 0-01161-0231-4)

Foundation Grants Index 1974; A Cumulative Listing of Foundation Grants. Lee Noe, grants ed. New York: Foundation Center; dist. by Columbia Univ. Pr., 1975. 315p. (LC 72-76018) (ISBN 087954-006-0)

Fuller, Sara. ed. The Ohio Black History Guide. Columbus: The Ohio Historical Society, 1975. 221p. $\$ 10.00$. (LC 7515426) (ISBN 0-87758-005-7)

Grele, Ronald J., ed. Envelopes of Sound; Six Practitioners Discuss the Method, Theory and Practice of Oral History and Oral Testimony. Chicago: Precedent Publications, 1975. 154p. \$7.50. (LC 74-18910) (ISBN 0-913750-87-7)

Guide to Football Literature. Ed. by Anton Grobani. Detroit: Gale, 1975. 319p. (LC 75-1478) (ISBN 0-8103-0964-5)

Hall, N. John. Salmagundi: Byron, Allegra, and the Trollope Family. (Beta Phi Mu Chapbook, no.11). Princeton, N.J.: Beta Phi Mu, Princeton University, 1975. 105p. \$7.00. (LC 75-1156) (ISBN 0910230-11-0)

Holler, Frederick L. Information Sources of Political Science. Santa Barbara, Calif.: ABC-CLIO, 1975. 5v. \$24.50.

Industrial Research Laboratories of the United States. 14th ed. New York: Bowker, 1975. 585p. \$49.75. (LC 21-26022) (ISBN 0-8352-0787-0)

Key, Jack D., ed. Library Automation: The Orient and South Pacific: A Report on the LARC Delegation's Meetings and Visitations with Counterparts in Japan, Hong Kong, Singapore, Australia and New Zealand in January 1974. Tempe, Ariz.: LARC Association, 1975. 96p. (ISBN 0-88257-200-8)

Library and Reference Facilities in the Area of the District of Columbia. 9th ed. Ed. by Mildred Benton. Washington, D.C.: American Society for Information Science, 1975. 250p. \$10.44, members. 